\title{
Public Virtual Rooms of Learning and Social Identity: An Emerging Technology Resource
}

\author{
Hadinei Ribeiro Batista, Maria Cecilia Mollica \\ Department of Linguistics, Federal University of Rio de Janeiro, Rio de Janeiro, Brazil \\ Email: hadinei@gmail.com, ceciliamollica@terra.com.br
}

Received 15 March 2014; revised 15 April 2014; accepted 22 April 2014

Copyright (C 2014 by authors and Scientific Research Publishing Inc.

This work is licensed under the Creative Commons Attribution International License (CC BY). http://creativecommons.org/licenses/by/4.0/

(c) (i) Open Access

\begin{abstract}
Currently, we observe a gap in terms of technological resources used in the teaching-learning process in networks of public education in Brazil and the lack of detail of the social identity of the subjects included in this process for the implementation of more effective public policies for a more inclusive and democratic education. This text discusses on the implementation of public virtual rooms of learning in elementary and high schools, with strict control of social factors, as complementary to the traditional education method still in force. It is intended: 1) to present and discuss a matrix of control of social identity for diverges cycles in which education takes shape, 2) to introduce a first model of formatting of these virtual rooms for each cycle of the education so that the control of social factors might be in accordance with the Brazilian Nacional Council of Education (Brasil, 2010) and the guidelines of the LDB (Lei de Diretrizes e Bases da Educação) (Brasil, 1996) for each stage/cycle of the current educational process, 3) to examine the advantages of this new tool in mainstream education.
\end{abstract}

\section{Keywords}

Social Identity, Education, Computers, Educational Guidelines, Internet, Virtual Environments

\section{Introduction}

The main objectives of ongoing research, exposed in the opening section, foresee the construction of virtual learning environments, monitored through identity matrices used in the registration system.

Before dealing specifically with formatting and functionality of such environments, we seek to fractionate, in educational cycles, the matrix of control of social identity proposed by Batista and Mollica (2014b). This fractionation is crucial for compatibility between the information required in the matrix and its appropriateness to the stage of psychic development of individuals in the learning process. If each school cycle or step corresponds 
to a specific time of the construction of social identity of the student, the reference matrix suggested by the authors may not be the same for all levels. The following section discusses in more detail the suitability matrix for these different steps.

\section{Rescuing Social Profile in Different Learning Cycles}

Batista and Mollica (2014b) presented a first version of an identity matrix of control of social factors. The overall goal of the matrix is to subsidize research in sociolinguistics and to build a user registration system for use of public virtual rooms of learning to assist the elementary and secondary education, whose construction is part of the objectives of the ongoing research. The matrix presents a wide range of features that enables the researcher to get closer to details of social identity of individuals filtered by it. The images (Figure 1 and Figure 2) are a reproduction of such a matrix.

This matrix contains identity traces collected in different domains (registration information from different government departments, social networking sites, financial monitoring sites, acquiring visas) arranged in two major categories: objective and subjective. The adequacy of the matrix to different cycles in which the basic education set up is of paramount importance for the monitoring of virtual environments in discussion and so that we can respect each phase of construction and recognition of the social identity of the subjects. Batista and Mollica built those different matrices, however they will not be introduced here.

Before proceeding, it is recorded that the notion of social identity adopted here assumes meanings of different authors, who characterize and define identity as: 1 ) set of shared fundamental cultural values; 2 ) have relational

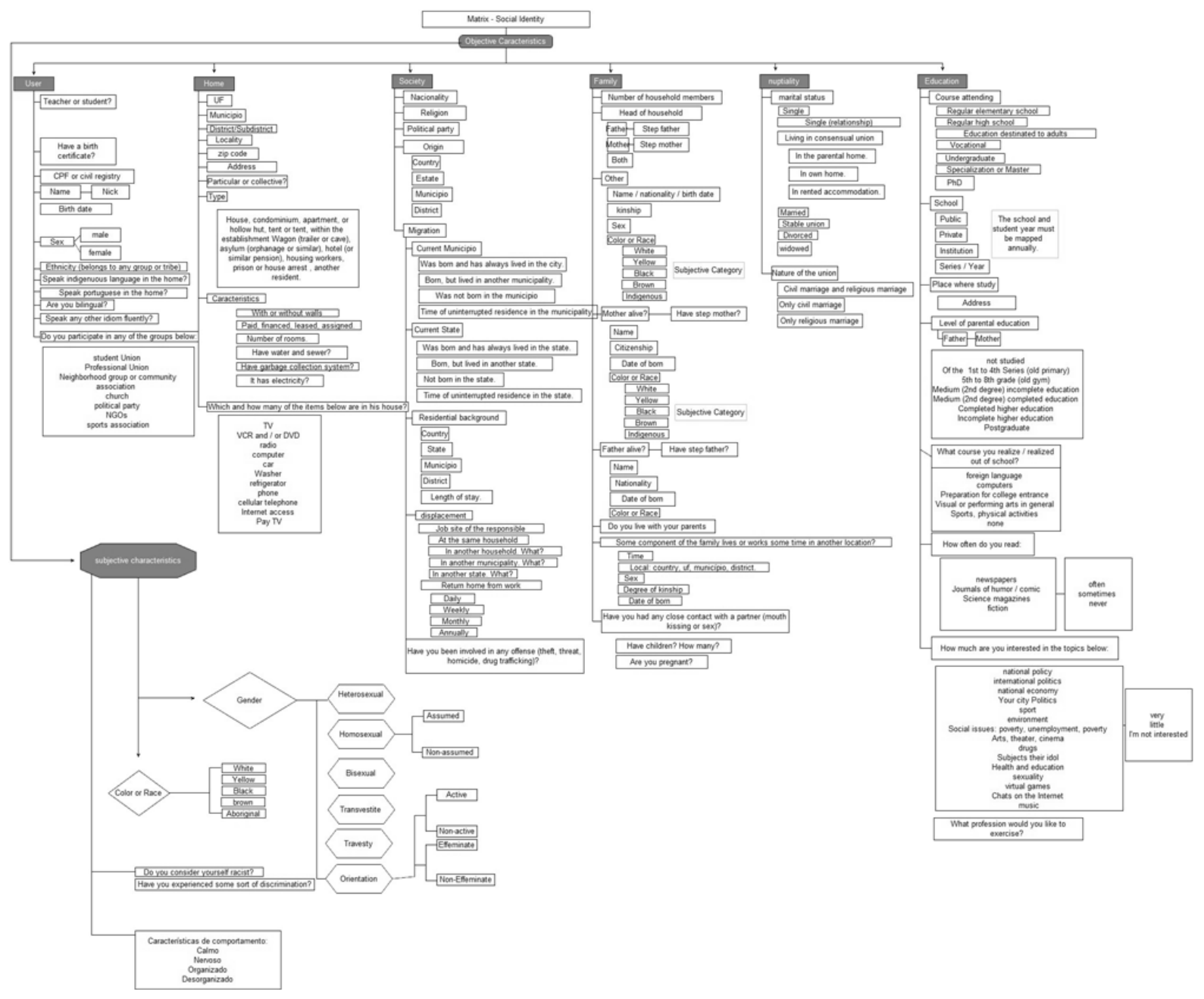

Figure 1. Matrix 1. 


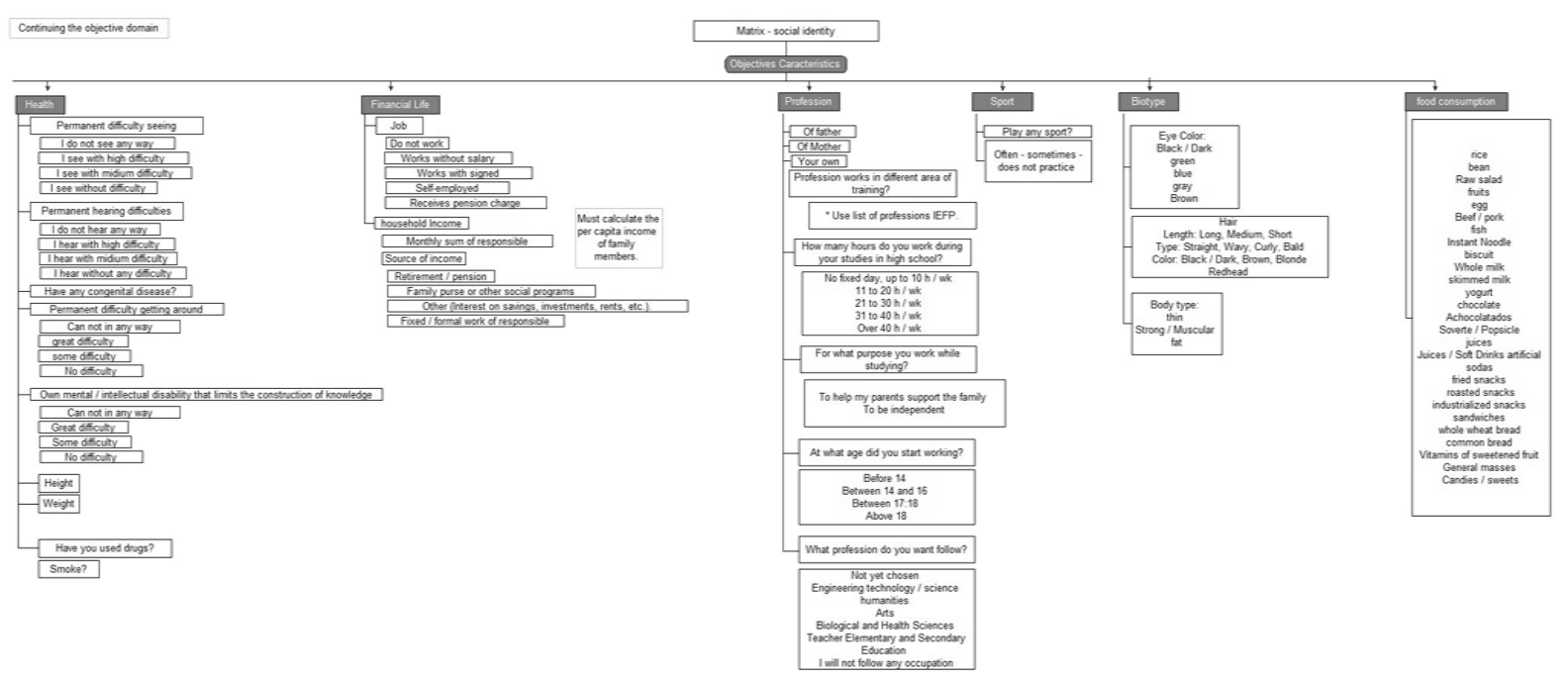

Figure 2. Matrix 2.

character, based both on the similarity (in the case of recognition of groups of people) and the difference (in case of recognition of a single individual); 3) form of individualized expression of the structure of symbols of the social world in which we live; and 4) marked by interactive processes and therefore fragmented, multiple, variable and provisional (Oliveira, 1976; Brandão, 1986; Damata, 1998; Marcia, 1980; Hall, 1992, 2006; Santos, 2008; Silva et al., 2003; Silva, 2012).

The format of the matrix above followed the model of the last census conducted by IBGE (Instituto Brasileiro de Geografia e Estatística). The institution categorizes identity features in small groups (territory, education, profession, etc.). This facilitates data collection and organization of the registration screens to request information during the registration process of the users of the virtual environments in theory. The main objective of detailing the social profile of these students is the importance of this control to support academic research in order to better understand how social factors relate to the process of construction of knowledge by learners as well as the use they make of the language. Thereby, it will be possible to diagnose, in more fruitful way, the factors involved in the process of linguistic variation and change, since the environment will favor the construction of a corpora with different levels of language use: text, voice and video.

\section{Public Virtual Rooms of Learning-PVRL}

A major objective of the PhD project in progress is the development of public virtual environments of learning. Virtual education is a reality in Brazil since the 70s. However, we observed a gap in the use of this technological tool as a complementary alternative to the traditional public basic education. Batista and Mollica (2014b) succinctly described the formatting and functionality of such rooms, whose main claims we will condense so.

The traditional public school around the world, into force, set up in a physical space where a group of students interacts with a specific teacher. In other words, the relationship is between a complex and diverse set of identities (students) and a single teacher who, in turn, also has an identity matrix. It turns out that this relationship is restricted because a single teacher needs to encourage and ensure the construction of knowledge by a group of young people with skills, interests and ways of learning that are unique to them. One way to address this challenge would be the expansion of networks between students and teachers far beyond the physical space of the classroom. For this purpose, the virtual environment is shown highly promising.

In traditional education, students, in the classroom, have contact with only one teacher explanations, with who they tend or need to solve your questions and promote their learning. In case of failure of this interaction, or the student tries to overcome his difficulties autonomously or awaiting the opportunity to interact with another teacher, if not in the same year, maybe in the next one. The tasks proposed by the school, known as homework, are also another challenge that the student seeks to solve autonomously, sometimes exploring unreliable websites or requiring possible aid from their families. The virtual rooms of learning that we propose now reach the merits of assisting students, extending their networks of contact and providing a way of building knowledge 
more flexible, democratic and respecting the individuality of each student.

Such virtual rooms are not at all a novelty. Some private institutions, regular or preparatory education for enrolling in universities, already use the virtual environment to facilitate contact between students and teachers in flexible hours to attend the needs of these young people in their learning processes. Such environments are very specific, accessed by students to address questions and/or explanations of certain content indicated by the institution. In that environment, students can also find teaching materials, tips and even classes if the student has been absent from some. However, these environments have exclusive access by the students enrolled in the course and the educational interactions revolve around the content that the institution offers. Furthermore, there is in general no commitment to monitoring the identity of the people who use the virtual room. The requisitions to inscribe on such environment little go further of the registration of a login and of a password.

Given the potential that this tool offers for education, our interest is to build public virtual rooms of learning, monitored by identity matrices and respecting each educational cycle proposed by national parameters of education. The following section shows better the set up of the virtual rooms under discussion, the inclusion of identity matrices and highlights its advantages for assistance in implementing public policies for education and the promotion of a quality education, public, democratic and able to consider the specific needs of each student. Beyond this, such tool will allow us to build an efficient corpora for academic studies on language.

\section{Public Virtual Rooms of Learning: Formatting and Identity Control}

We anticipate that the operating parameters for the construction and formatting of virtual rooms will be provided by the field of computing. The forecast is a virtual environment for each area of knowledge matched to each phase of education. Thus, the student, who has difficulty or interests in Portuguese, will access a specific virtual room of this area. The same will occur for mathematics, physics, chemistry, geography.

To access such environments, students must fill out a registration consisting of all the features present in the identity matrices proposed in our research, which was reproduced at the previews section. Only through this filtering of social identity, the student will be enrolled on the environments. The advantage of it is that it promotes the possibility of mapping each student, considering their history of life, your social profile. With this monitoring, it will be possible to develop research to understand how learners deal with the construction of knowledge and investigate which social factors may be involved in their difficulties, failures and lag. More than that, it will be possible to map out precisely the most areas required by students, the topics/content are more addressed or generate more questions. All this is provided by a technological resource capable of generating results in seconds: the computer.

Besides the registration of students, it will also be done the registration of teachers. The identity matrix for teacher will be the full one present in the preview section. As we already have said, the matrix for students will be matched with their level of learning or according to their ages. Teachers should insert the traces of their social identity, as well as include and make available their résumé. Just as occurs for students, teachers might be monitored according to their profiles. It will permit propose implementation of public policies and teacher training courses in a precise way, considering the performance of these teachers when assisting students. It will be yet possible to know whether a particular teacher X, from a X school, guides his/her students in the construction of knowledge according to the latest dictates of the area of training. In the same school or among schools of a city, there may be teachers in opposite directions in the performance of its function. Training courses may be offered, listing, in town or in the institution, the teacher who is more up to participate in the training of their colleagues. Several other factors may be investigated and diagnosed like as the contribution of the teacher training college in the performance of its activity.

According to the identity matrix, each student and/or teacher must insert the school where they study/work, the cycle they are in. Thus, when a student accesses the virtual environment (regardless of the chosen area of expertise), it appears to all registered teachers on the platform. Besides, it is shown indications of who is or is not online at the moment, plus a link to check the teacher's curriculum. If the student belongs to the 2nd cycle, for example, he/she will only interact with teachers who teach in this cycle.

Each room will present a simple formatting. Upon entering the chosen environment (Portuguese, Mathematics), the student will have access to online teachers. He/she will choose the teacher he/she wants and a window will open for interaction between them. The student can type his/her question or request for guidance or h/s can choose to put the question in a "voice" or even choose a channel face time. All interactions would be recorded 
and would be made available for academic research, considering, of course, all of the guidelines of ethics on the violation of privacy. In addition to these resources, teachers can post lessons, texts, tips, videos and other materials that can guide students in constructing knowledge.

Just as the traditional physical space of learning, social environments of interaction are also foreseen. Virtual recreation rooms, informal social networks for sharing daily experiences among students, informal chats. Teachers may also propose virtual environments for discussion, for students make presentations. Likewise, there may be environments of interaction among teachers to share challenges, exchange materials, among others.

The virtual rooms will have public and democratic character, governed by national education guidelines. It is noteworthy that such rooms are an extension of the physical space of the classroom and the policies which govern the traditional education also extend to the virtual environment. More than that, the rooms, being virtual, will be spread out throughout the country. Any student or teacher of any state, city, institution may join.

Before concluding, we emphasize that public virtual rooms provide an alternative and complementary space. This is not an environment in which students need to have a mandatory access on a fixed schedule and with the goal of accomplishing tasks and workload. It is a free helping virtual space available to students and teachers. They will be free to access it whenever. No student shall be subjected to reviews or other formal procedure laid down in the curriculum of their classroom course. If the student needs, the space is there. Instead of searching for information on untrusted sites, it now offers a safe environment with trained professionals to assist them. The "fever" of the moment is the development of applications for "androids". Each virtual room may also be configured in an application and the student will have access to a classroom in the palm of his/her hand.

\section{Some Advantages}

Several advantages that this environment provides were partly mentioned in the previous section. The main one is the monitoring of student's and teacher's identity, which favor the implementation of public policies more efficient, precise and particular. We are also in the digital age and with huge potential. The attention to the particularities of the pupil with respect to their individual process of knowledge construction is an emergent and a urgent task. They practically have a virtual life. The network provided by this environment enables the learner to choose who will teach him/her, who meets their prerequisites to help them bulid the knowledge. And of course, promotes digital inclusion and access to knowledge of needy students and also with special needs. Finally, these virtual environments will constitute a huge corpora to attend to the academic research, regardless they take into account social factors or not.

\section{Conclusion}

The objective of this article was to argue for the construction and implementation of public virtual rooms of learning as an auxiliary force to the traditional education. Such environments would be monitored by matrices of identity like proposed to hold up the implementation of public policies.

The matrix outlined before is a full model. However, it is necessary to have different matrices for each fase/ cycle of the education. Some features of human identity cannot be described depending on the age. Batista and Mollica (2014b) outlined one matrix for each cycle. We reproduced here only the full one, which would be applied to teachers in general. This article also detailed, thoroughly, the formatting and the functionality of the virtual rooms of learning in thesis and it presented a set of advantages that derives from its ideological and operational proposal.

It is also worth noting that the ongoing research includes the construction of corpora from virtual learning environments, strictly controlled by social factors. This gap has not been satisfactorily completed by scholars of corpus linguistics (Baker, 2010; Sardinha, 2004a, 2004b; Biber, 1998; Dash, 2010; Kendall, 2011; Kennedy, 1998; Oliveira, 2009; Raso \& de Mello, 2012; McEnery, 2001, 2006), especially with regard to restricted and detailed control of the social identity of users/informants.

\section{References}

Baker, P. (2010). Sociolinguistics and Corpus Linguistics. Edinburgh: Edinburgh University Press.

Batista, H. R., \& Mollica, M. C. (2014a). Identidade social, tecnologia e educação: Relação necessária? Forthcoming. http://www.4shared.com/office/Mm7zsXEnce/Identidade_social_tecnologia_e.html 
Batista, H. R., \& Mollica, M. C. (2014b). Maria Cecília. Fatores Sociais: Matriz de referência. Forthcoming. http://www.4shared.com/office/ackVheX6ba/matriz_de_referncia_fatores-so.html

Biber, D., Conrad, S., \& Reppen, R. (1998). Corpus Linguistics: Investigating Language Structure and Use. Cambridge: Cambridge University Press. http://dx.doi.org/10.1017/CBO9780511804489

Brandão, C. R. (1986). Identidade e etnia: Construção da pessoa e resistência cultural. São Paulo: Brasiliense.

Brasil (1996). Ministério de Educação e Cultura. LDB-Lei $n^{\circ}$ 9394/96, de 20 de dezembro de 1996. Estabelece as diretrizes e bases da Educação Nacional. Brasília: MEC, Batista. 1997. Secretaria de Educação Fundamental. Parâmetros curriculares nacionais: Introdução aos parâmetros curriculares nacionais/Secretaria de Educação Fundamental (p. 126). Brasília: MEC/SEF.

Brasil (2010). Ministério da Educação/Conselho Nacional De Educação. Parecer CNE/CEB No. 07/2010.

Damata, R. (1998). O que faz do Brasil, Brasil? Rio de Janeiro: Rocco.

Dash, N. S. (2010). Corpus Linguistics: A General Introduction. Proceedings of the Workshop on Corpus Normalization, LDCIL, CIIL, Mysore, 25 August, 1-25.

Hall, S. (1992). The Question of Cultural Identity. In: S. Hall, D. Held and T. McGrew (Eds.), Modernity and Its Futures. Milton Keynes. Cambridge: Open University Press.

Hall, S. (1999). A identidade cultural na pós-modernidade. Trad. Tomaz Tadeu da Silva, Guarareira Lopes Louro (11 ed., 104 p). Rio de Janeiro: DP \& A Editora.

Kendall, T. (2011). Corpora from a Sociolinguistic Perspective (Corpora sob uma perspectiva sociolinguística). In Th. G. Stefan (Ed.), Corpus Studies: Future Directions, Revista Brasileira de Linguística Aplicada, 11, 361-389.

Kennedy, G. (1998). An Introduction to Corpus Linguistics. London: Longman.

Marcia, J. E. (1980). Identity in Adolescence. In J. Adelson (Ed.), Handbook of Adolescent Psychology. New York: Wiley.

McEnery, A.M., \& Wilson, A. (2001). Corpus Linguistics (2nd ed.). Edinburgh: Edinburgh University Press.

McEnery, T., Xiao, R., \& Tono, Y. (2006). Corpus-Based Language Studies: An Advanced Resource Book. London: Routledge.

Oliveira, L. P. (2009). Linguistica de corpus: Teoria, interfaces e aplicações. Matagra, 16.

Oliveira, R. C. (1976). Identidade, etnia e estrutura social. São Paulo: Biblioteca Pioneira de Ciências Sociais.

Raso, T., \& de Mello, H. R., (2012). C-ORAL-BRASIL I: Corpus de referência do português brasileiro falado informal. Belo Horizonte: Editora UFMG.

Santos, E. N. (2008). Adolescence, Homossexuality, Gender: Social-Historical Psychology as a New Path. Revista de Psicologia da UNESP, 7, 1-11.

Sardinha, T. B. (2004a). Lingüística de Corpus. São Paulo: Manole.

Sardinha, T. B. (2004b). Lingüística de Corpus: Uma entrevista com Tony Berber Sardinha. Revista Virtual de Estudos da Linguagem, 2.

Silva, A. C. C., Adan, S., Luiz, F., \& Fernando, F. (2003). Crescimento em Meninos e Meninas com puberdade precoce. Arq Bras Endocrinol Metab, 47, 422-431. http://dx.doi.org/10.1590/S0004-27302003000400014

Silva, P. O. M. (2012). Adolescentes e homossexualidade: Representações sociais e identidade social. Cadernos de Pesquisa, 42, 474-493. http://dx.doi.org/10.1590/S0100-15742012000200009 